\title{
Fading away at work: "I could have left without saying anything" - performing talent management in a multinational organization
}

\author{
Nanna Gillberg and Ewa Wikström \\ Department of Business Administration, School of Business Economics and Law, \\ University of Gothenburg, Gothenburg, Sweden
}

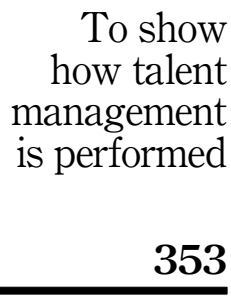

Received 29 January 2021 Revised 4 May 2021 29 June 2021

Accepted 29 July 2021

\begin{abstract}
Purpose - This study was undertaken in order to show how talent management (TM) was performed in practice in a multinational organization as well as how the TM practices affected both different groups of workers and the perception of talent within the organization.

Design/methodology/approach - Performing talent management was reassessed in the relationship between TM practices, view and identification of talent, attributed positioning and self-positioning of older and younger workers; retrieved from an exploratory single case study in a multinational organization, based on interviews.

Findings - The findings illustrate that despite the struggling to fill key positions with skilled workers, the studied organization adopted approaches to TM that excluded older workers' talent. First, central to performing TM was how talent was viewed and identified, and second, two types of positioning acts were important: the organizations (re)producing of talent management through attributive positioning acts on older/ younger workers and older workers' self-positioning of their own talent. The two sides of performing talent management were complex and intertwined resulting in an age-based devaluation of talent at work.

Practical implications - The study points to important issues in designing and performing TM that may be useful to HR and managers as a point of departure in the development of more inclusive approaches to TM. Originality/value - The concept "performing talent management" was developed as an intertwined relationship between on-going positioning acts and (re)production of status, talent and age at work; recognizing preferences of what was viewed and identified as valued talent as main drivers made it possible to develop an understanding of exclusion and inclusion mechanisms in performing TM.
\end{abstract}

Keywords Talent management, Valuation of talent, Status, Attributive positioning, Self-positioning, Older workers, Younger workers

Paper type Research paper

\section{Introduction}

In the wake of societal challenges related to demographic change, rapid technological development and increasing inequality issues, talent management (TM) has been gaining growing attention among both researchers and practitioners (Gallardo-Gallardo et al., 2015; Collings and Mellahi, 2009). Talent management practices of organizations, e.g. talent acquisition and retention and career development, play a central role in the ability to meet contemporary challenges. Global talent management (GMT) is most frequently defined as the

\footnotetext{
(C) Nanna Gillberg and Ewa Wikström. Published by Emerald Publishing Limited. This article is published under the Creative Commons Attribution (CC BY 4.0) licence. Anyone may reproduce, distribute, translate and create derivative works of this article (for both commercial and non-commercial purposes), subject to full attribution to the original publication and authors. The full terms of this licence may be seen at http://creativecommons.org/licences/by/4.0/legalcode

This research was funded by FORTE in Sweden Dnr 2015-01006 and by UGOT Challenges, University of Gothenburg. The researchers are associated with the Centre for Ageing and Health (AgeCap), University of Gothenburg, Sweden.
}

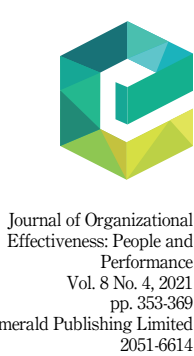

DOI 10.1108/JOEPP-01-2021-0020 

JOEPP process of attracting, selecting, developing and retaining highly performing co-workers in the global, most central positions (Collings et al., 2019; Vaiman et al., 2012).

Lahtukha (2015) highlights that TM is regarded as increasingly important since organizations are struggling to find talent and there is a shortage of qualified workers. Holland and Scullion (2019) argue that the war for talent increases the importance of focusing on the retention of talent within global companies and the psychological contract in regards to talent retention. This war for talent has also intensified due to continuous technology-driven changes in professional working methods. In other words, technological development is driving changes in professional practices and the demarcation between different forms of talent, which could result in new forms of inclusion and exclusion mechanisms in organizations' TM. Furthermore, in tandem with the digital transformation of professional practices, the workforce is also aging (Van Dongen and Loos, 2018). Future competence maintenance will hence rely on workers remaining in the labor market for longer. Against this background, detailed knowledge of the TM used by HR personnel and managers as well as of how older workers' talent is positioned when technology comes into play is highly needed. This study aims to highlight how managers, HR and older workers engage in TM in response to technological developments and digital transformation of work practices, and how the types of changes present influence how TM is performed in practice.

Studies conducted before the digital transformation of work life have shown age-based devaluation of professionals to occur already at the age of 40 and to increase progressively as professionals approach the normative retirement age (Ahmed et al., 2012; Neumark et al., 2019). Age-based devaluation of professionals' talent may be rooted in managers' negative stereotypes of older workers (e.g. Chiu et al., 2001; Remery et al., 2003). Managers for example have been shown to associate increasing age with stagnation and inability or unwillingness to learn (Furunes and Mykletun, 2007). The emerging emphasis on digital technology within organizations might serve to strengthen and reinforce age-based divisions and contribute to negative perceptions of older employees. Categorizations such as digital natives and digital immigrants can contribute to creating an age-related line of division between workers according to which older workers are perceived to be at a disadvantage. Loretto and White (2006, p. 326) have suggested that employers may hide negative attitudes toward older professionals "behind apparently neutral, institutional barriers, using them as a pretext to justify their discriminatory practices". Digitalization may provide a barrier that is conceived of as neutral and that can conceal managers' negative attitudes behind objections to older professionals based on their ability to handle digital technology.

In the wake of digitalization, mobility norms have been brought to the forefront (Faist, 2013; Sheller, 2014; Sheller and Urry, 2006), emphasizing movement, labor flexibility and propensity for change as desirable properties (Rubery et al., 2016). The increased speed facilitated by digital technology has spurred on shorter and faster cycles and bred a penchant for newness that tends to be associated with young age (Riach and Kelly, 2015). Mobility becoming a soughtafter characteristic might incur inclusion and exclusion processes and social hierarchies (Faist, 2013; Jeanes et al., 2015). This is especially relevant for the future since highly qualified workers of the next generation seem to be less attached to any particular place or national identity (Kerr et al., 2016). Moreover, the mobility norms might put older workers at a disadvantage in the labor market as worker mobility can be expected to decrease with age as a result of the demand for a worker's labor diminishing with increasing age (Riach and Rich, 2006, 2010; Lahey, 2008). The high likelihood of an older worker's seniority capital being local and linked to a specific organization may further increase the incentives for older workers to stay with an employer.

The previously concluded age-based devaluation might be underpinned by the focus of "business case" norms related to digitalization on aspects that can be linked to perceptions of knowledge and age. Situated knowledge, social talent and reliability - qualities that older professionals are often associated with - tend to be viewed as "soft" and hence valued lower than the technical qualities that younger professionals are associated with. These are 
categorized as "hard" and valued higher as they are thought to contribute to productivity and profitability to a higher degree than "soft" qualities (Van Dalen et al., 2010). The "business case" norms and their relationship with age can also be related to the influence in many organizations of new public management (NPM) ideas, through which the measurability of qualities and productivity is emphasized.

TM as an organizational practice could be designed and rooted in implicit perceptions of talent, age and seniority/juniority, which could have implications for how inclusion and exclusion is (re)produced through the use of TM. This has received little attention compared to research on macro-conditions and individual circumstances (Flynn, 2010). Several studies on how macro-conditions affect inclusion and exclusion of senior workers talent, for example the role of pension systems, i.e. institutional conditions outside the workplace (Coile, 2015), and on how micro-conditions affect inclusion and exclusion of senior workers talent, for example the individual's ability to fulfill work demands (Ilmarinen, 2012). From an intersectional perspective on TM, age management and digital transformation of the global work life, it can be argued that more knowledge is needed concerning organizational practices at the workplace level. Hence, more knowledge is needed on the impact of organizational practices in workplaces, and how inclusion/exclusion mechanisms are (re)producing talent, age and seniority/juniority and its consequences for diversity in talent when digital technology comes in to play.

Previous research on TM has also highlighted the importance of inclusion and exclusion approaches to TM, either focusing on all employees or aimed at attracting and retaining a selected group of employees with a specific type of talent (Dries, 2013; Meyers and Van Woerkom, 2014). Despite the advancement in TM research on inclusion and exclusion approaches, these questions are still underexplored in regards to how TM practices are designed and acted out in manager-worker interaction at the workplace level. Thus, the research is sparse on how this interaction could be rooted in implicit perceptions of talent (re) produced in the interplay between performance, productivity, age and seniority/juniority with implications for who and what should be considered talent in the organizations. Particularly, knowledge on how digital technology affects the conditions for and retention of different groups in an organization is lacking. Accordingly, limited empirical research exists on how inclusion and exclusion mechanisms embedded in TM may influence inclusion and exclusion of talent, age and seniority/juniority, and how employer and employee agency through such TM practices correspond with each other (e.g. Munnell et al., 2018).

We argue that a focus on the intersection of age and talent is both theoretically interesting and practically important because it may influence how TM strategies and practices are organized and what effects they have. A deeper understanding of how the intersection between age and talent unfolds in TM narrative strategies and practices on workplace level can enhance the understanding of performing TM in practice. In an era of digital transformation of professional practices and an aging workforce, struggles around the valuing of talent are likely to become increasingly common and be played out in organizations. In this article, we studied positioning acts related to the recognition of older employees' talent within an organization, aiming to gain insight into how the positioning acts interact to produce certain outcomes. The positioning acts represent negotiations, whose effects have bearing on the diversity of talent within an organization. As a starting point for our studies of how TM was performed in practice and what implications it had for positioning of older workers' talent, we posed the following questions:

$R Q 1$. How is talent viewed and identified?

$R Q 2$. How is the organization's way of doing things perceived by employees in regards to understanding and procurement of talent?

RQ3. How do older workers perceive themselves and their talent?
To show how talent management is performed

355 
JOEPP 8,4

RQ4. What characterizes the interplay of valuation of talent and age?

\section{Theoretical framework: norms, status and positioning processes}

$\mathrm{Ng}$ and Feldman (2014) and Dickmann et al. (2018) have highlighted the importance of a changed and more dynamic perception of GTM including the value of structural social capital and experience from social networks and international relations. However, previous research has brought attention to the difficulty in retaining such tacit knowledge built on long experience within organizations (Vaara et al., 2012) as the specific characteristics of the knowledge complicates its visibility and embodiment (Nonaka and Takeuchi, 1995). Ng and Feldman (2014) show that career development systems in many organizations are based on perceptions of talent linked to who is regarded to be "top talent" or "rising stars". What is considered relevant talent might be subject to change by various organizational transformations, for example when digital technology comes into play in an organization.

Gallardo-Gallardo et al. (2013) have concluded that organizations in practice often combine inclusive and exclusive TM approaches in order to construct distinctions between their employees and to create TM systems. How talent is defined has important implications for how inclusion or exclusion of TM unfolds in practice (Dries, 2013; Meyers and Van Woerkom, 2014). One such distinction is whether a specific type of talent is given status and seen as highly important in order to perform pivotal tasks and positions (McDonell et al., 2017). In the article "Status Processes in Enduring Work Groups", Cohen and Zhou (1991) use the status characteristics theory to explain the basis of group members' status and the processes that lead to a certain status within a group. The theory deals with the processes that, based on the norms, values and perceptions of people from different groups, result in different degrees of status, which, in turn, create inequalities in the social interaction between people. The authors note that talent and performance are not the only factors based on which someone is assigned status. This is instead related to the interaction between (1) an individual's position in society, (2) an individual's position in the organization and (3) an individual's performance in the group in the production of status around people.

A status characteristic is an attribute that affects a person's valuation. Cohen and Zhou have concluded that age is a status characteristic, gender is another. Status characteristics can either be general, i.e. extend over a range of situations and areas, or specific, i.e. limited to a certain situation. General status characteristics are, e.g. gender and ethnicity, categories that may have significance for status attribution in a wide range of contexts related to, for example, hiring, promotion, role allocation and compensation. For example, a specific status characteristic would be mathematical talent in a situation where a mathematical problem is to be solved, and where mathematical skills thereby give status. The status characteristics can also be categorized as external and internal. External status characteristics, e.g. gender and seniority, are characterized by the fact that their social significance is given in advance and outside of the situation where there is interaction around a task. These are defined by the community or organization rather than by the group in a given situation. Internal status characteristics develop and become important in or as a result of a particular situation. An example is the award "Employee of the Month". The theory of status characteristics illustrates how inequalities are created in group interactions through several different principles and is applicable to a study of age in working life. Examples of such principles are: (1) the activation principle, according to this principle age could demonstrate a status characteristic associated with negative status, which is activated in the meeting with new/ digital technology; (2) the combination principle describes essentially the same phenomenon as the concept of intersectionality; (3) the principle of relevance means that something is relevant either because it has an obvious significance for the performance of a particular task or becomes relevant through an evidentiary process based on a certain status-related notion 
of a specific category of persons and (4) the translation principle takes into account the contextual nature of the status characteristic theory and the phenomenon that the different or positive statuses of the different characteristics relate to the situation and context as well as to the actors involved. The status charge may vary and whether something is perceived as relevant information in status terms and in relation to the performance of the work may vary with context.

Thus, the Cohen and Zhou (1991) framework could be used to analyze status characteristics on the intersection of talent and age. The status of older workers' talent could influence the positions of older workers at the workplace level as well as their continued employment. Czarniawska (2013) combined the two tensions (inclusion vs exclusion and attributive positioning vs self-positioning). This framework could be used for analyzing the discursive negotiation and production of selves as four different types of positioning acts in performing TM in practice. The four different types of positionings are constructed based on two types of interrelated positioning processes: self-positioning and attributive positioning. Self-positioning concerns self-representation, and, for example, how you present your talent to others. Attributive positioning refers to others presentation and positioning of particular individuals or groups. Czarniawska combines the two positioning processes with two types of possible results of positions in order to present a framework that could be used in analyzing types of positioning acts and their possible results. This framework is presented by four combinations:

(1) The combination of attributive positioning and positioning accepted could result in two possible positions of talent: (1) maintaining position or (2) shifting position.

(2) The combination of attributive positioning and positioning contested/resisted could result in two possible positions of talent: (1) refusing definition or (2) re-positioning (intersections).

(3) The combination of self-positioning and positioning accepted could result in two possible positions of talent: (1) managing position or (2) losing position.

(4) The combination of self-positioning and positioning contested/resisted could result in two possible positions of talent: (1) performance faulted or (2) performance unrecognized (divergent definitions).

In sum, the theory on status processes (Cohen and Zhou, 1991) and interactive production of selves through positioning processes (Czarniawska, 2013) will be used as analytical frameworks in this study on how managers, HR and older workers engage in performing TM, and how the types of positioning acts influence the valuation of age and talent at work.

\section{Methodology \\ Design, participants and data collection}

This study involves a global manufacturing company, based in Scandinavia, while operating in a global market with some 42,000 employees spread across operations in Europe, Asia and North America. A qualitative single case study forms the basis for the research design of the data collection in this article. The choice of a qualitative single case study as a research design has been made based on the aim of the research to gain a more detailed understanding of how TM was performed in practice in a multinational organization as well as how it relates to the perception of talent within the organization (cf. Czarniawska, 2014; Silverman, 2013). The choice of case study method is based on and supported by our theoretical framework of TM and GTM as a TM practice, which proposes that researchers are able to increase the knowledge of questions related to the dynamics of practice (Kaghan and Lounsbury, 2011). This framework is particularly useful because it assists in analyzing how existing norms and

To show
how talent
management
is performed

357 
JOEPP

practices are maintained by actors inside and around organizations. Furthermore, the case study approach and interviews with managers and older workers, effectively taps into the attributive and self-positioning within a shared organizational context in focus in the present article.

The case study has involved data collection with all relevant actors within the organization which includes managers, HR specialists, trade union representatives and employees. The four first mentioned categories have, in different capacities, formal responsibilities for TM within the multinational company. To get a detailed understanding of how TM is practices, we also needed to know about individual conceptions, attitudes and collective norms toward TM, older workers and prevailing informal normative discourses. For this reason, as part of the data collection was conducted by individual interviews, focus group interviews and document analysis to study these aspects.

The first step in collecting qualitative data consisted of reading documents that included the company's HR policies on recruitment, promotion and internal documents regarding knowledge management. The next step of the data collection consisted of an interview study with relevant actors within the organization, including managers, HR specialists and older employees. To understand the construction of older workers' talent, we need to know about individual attitudes and collective norms toward talent and prevailing informal normative discourses. For this reason, as part of the data collection, we have conducted individual interviews and focus group interviews. The interviewees consisted of nine managers interviewed individually, two HR managers were interviewed twice and 14 employees, 62 years and older, each of whom was interviewed once. We also conducted two focus groups. The participants in the two focus groups were chosen from the individual interviews with older workers. The two focus groups involved three participants each. All the interviewed employees in this study were salaried employees over the age of 62 . They worked in 11 departments in two locations in Sweden and had experience of working in the global company's foreign offices.

All interviews were open to capture the interviewees' variations of experience (Silverman, 2013). The interviews were semi-structured and included such themes as the interviewee's view of how TM was performed, how it affected different groups and the perception of talent within the organization. The participants in the focus group interviews were chosen from the group that was interviewed individually. The focus groups revolved around the results from the individual interviews, but the participants were encouraged to talk about their own experiences based on the results. In this way, we took an interactive research strategy (Morgan, 1997) with the individually interviewed employee to develop our interview results and to reflect on our preliminary conclusions. All interviews, including the focus group interviews, lasted 60 minutes and were recorded and transcribed to form the basis for analysis of the field material. The interviews were conducted in both Swedish and English depending on whether the interviewee was Swedish or English speaking. The interviews carried out in Swedish were translated by an authorized translation company.

\section{Data analysis}

Once the interviews were transcribed, all the interview transcripts were read several times. The first reading and the initial categorization of statements in the interview transcripts were marked using patterns and links in their descriptive content (Corbin and Strauss, 2008). The next step in the analytical work was done based on the chosen theoretical framework, in a search for themes to categorize talent, and how talent is positioned, especially in relation to the construction of status. The analysis was an iterative process of interpretation and sensemaking that began with initial interviews. After having read the transcriptions of each interview, the most important views and ideas were noted and reflected on in comments 
about interesting results. These notes also elicited new questions that were asked in the next interview and so on. This gradual, iterative process enabled an understanding of how talent TM was performed in practice in a multinational organization as well as how workers and the perception of talent within the organization emerged.

First-order empirical categories originally received such marks as

(1) How talent was viewed and identified

(2) How the organization's strategies and practices were perceived by employees in regards to understanding and procurement of talent

(3) How older workers viewed themselves and their talent

(4) What characterized the interplay of valuation of talent and age

These empirical categories influenced the choice of a theoretical framework that governed categorization of second-order theoretical categories and was then used to analyze and expand such theoretical categories as the positioning of talent and the production of status related to talent. The findings section of this article was structured according to theoretically founded second-order categories derived from the first-order categories above.

Finally, an iterative analysis of the data encoded in these categories was performed, with examples and illustrative quotes how talent is performed and positioned in practice (Denzin and Lincoln, 2011) (see Table 1).

We adapted a three-dimensional criterion to assess the rigor in qualitative research focusing TM practices in the studied organizational context. The three interpretative criteria comprised authenticity (in-depth understanding of the studied phenomenon in the studied organizational context through extended fieldwork), plausibility (developing understanding of local phenomena which made sense to participants and drawing these together into a coherent overall description) and criticality (critically questioning taken-for-granted assumptions, for example about who and what are central in the definition of talent) (Golden-Biddle, 1993). Using these three criteria (Golden-Biddle, 1993) to assess rigor in our study, supported the creation of a convincing argument.

\section{Findings}

In the findings section, we draw on Czarniawska's categories and constellations and show how attributed positioning and self-positioning related to the talent of older employees,

\begin{tabular}{lll}
\hline & Attributive positioning & Self-positioning \\
\hline $\begin{array}{ll}\text { Positioning } \\
\text { accepted }\end{array}$ & $\begin{array}{l}\text { Experience-based knowledge of older workers } \\
\text { is said by management to be valuable to the } \\
\text { organization }\end{array}$ & $\begin{array}{l}\text { Older workers perceive their talent as } \\
\text { valuable to the organization }\end{array}$ \\
$\begin{array}{l}\text { Positioning } \\
\text { contested/resisted }\end{array}$ & $\begin{array}{l}\text { Older workers' talent is seen as outdated by } \\
\text { management due to increased focus on digital } \\
\text { technology }\end{array}$ & $\begin{array}{l}\text { Older workers perceive their talent } \\
\text { related to digital transformation as } \\
\text { outdated }\end{array}$ \\
& $\begin{array}{l}\text { Older workers are moved into old products } \\
\text { that are on their way out }\end{array}$ & \\
& $\begin{array}{l}\text { Older workers' talent is not transferred, i.e. not } \\
\text { included in the TM practices }\end{array}$ &
\end{tabular}

Note(s): In the table depicting positioning acts and their results, the attributive positioning of management, is taken as the starting point to which the older workers' self-positioning is related

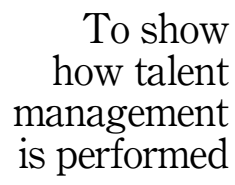

359

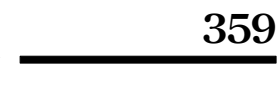



JOEPP

\section{0}

interact in the production of different outcomes. The second theoretical framework relates to status attribution processes, using status characteristics theory (Cohen and Zhou, 1991) to illustrate how inequalities are created in group interactions through status regulating principles such as age.

\section{Out with the old, in with the new: self-positioning and attributed positioning coincide in a} joint devaluation of older workers' talent

The attributed positioning and self-positioning may coincide or differ from each other. When the two types of positioning coincided in the present case, it resulted in older workers' talent either being denied or going unnoticed. This occurred when management's (here consisting of managers, employers and HR representatives) negative valuation of older employees' talent related to electrification, digital technology and new products was internalized through the older employees' positioning of their talent. Both the management and the older workers depicted the talent of older workers as dated and about to becoming obsolete. This perception was conveyed through the managers' attitude to knowledge transfer - in many cases seen as unnecessary and undesirable - and in the older workers' reference to their own competence as dated. Further contributing to the absence of positioning of older workers' talent was the TM strategy's focus on attracting young workers with technology-heavy skills.

The interviews with HR personnel and managers on perceptions of talent and TM practices reflected the overall business case description. The most frequently occurring description of how to work with TM was to recruit young people who are well-educated in the area of electrification and new technology. Some managers expressed reservations about this strategy and its consequences.

We have different opinions, my colleague wants younger people but not my view, I think we will miss a lot of talent. (Manager a)

One manager brought up difficulties associated with the strategy to phase out older workers to make room for younger employees.

Giving people older people than 63 retirement packages have been common in some periods. But it hasn't happened lately, latest 5-6 years. The drawback for the manager is that you cannot replace the person when there is cost-cutting. You need to leave some position. So, it's hard for the manager if people say yes to this package. (Manager c)

Older workers' susceptibility to new knowledge came into question in the following quote by a member of the HR staff.

Everyone is not open to receiving knowledge. Many of the older workers don't see the context, don't feel that they have time, the goals are tight and you have to deliver. (HR a)

The challenges raised by rapidly changing conditions were emphasized in the narrative on the business case approach of the company. The prescribed response to the changing conditions was equivalent change on different levels: the global societal level (to reach "sustainability goals" and to become a "climate-neutral company"), the customers' needs ("mobility" and "safety") and the products ("electrification" and "technological driven"). The perception of and approach to change was also described by HR personnel and managers as influencing the way that the company was working with TM and what practices were used in order to reach the company's goals to be a world leading company that drives change. The talent shift narrative was a frequently used depiction of the TM strategy in use. A highlighted practice within this narrative was the recruitment of young, "junior", well-educated people with some work life experience. Narrations on valuable talent, knowledge retention and older workers related to the introduction of new technology and electrification of the company's products. Some interviewees mentioned that knowledge within certain areas, particularly 
those that involved the use of new technology, became redundant quickly and therefore was not possible or even suitable to pass on from newer to older members of staff.

In work areas where you are working with new technique, there is no knowledge to retain or transfer since you are working with new stuff all the time. But on the other hand, it is always good to know how an organization is organized, that there are manuals for it, and why you do things in certain ways. (HR a)

The focus on electrification and new technology in the talent concept contributed to knowledge transfer not necessarily being seen as desirable.

Sometimes we do not want knowledge transfer since the knowledge is too old. (HR b)

The very need for knowledge transfer was hence in some cases questioned with reference to the short life cycles of relevant talent.

To be honest, I do not think we need much knowledge retention since there is soo many new things that happen all the time. (Employee d)

While the older workers generally valued and positioned their own knowledge and contribution to the organization, they adopted a more negative view of themselves when the knowledge was related to new technology and new products. The older workers in their selfpositioning then appeared to have internalized a view of their talent that they perceived their management to hold. Resulting from this internalization was a devaluation of the older workers' talent articulated by both management and the older workers themselves. The attributed positioning and the self-positioning of talent hence reinforced one another. In concordance with the negative views articulated by managers, older workers described, or thought of themselves as being perceived, as carriers of talent about to expire.

We are good in building and constructing good products, but in 10 years will anyone have one? Maybe not. All of us want to have a clean and quiet product, not the product we have today, I think. So, at some point there will be a shift and all these engineers won't be needed. That is my own reflection. (Manager a)

The perception of not being seen as a valuable resource was reinforced by a member of HR, who depicted the interest in having older workers stay in the workplace for longer as motivated in large part by changes in demographics and legislation.

There is a large interest, not at least in manufacturing units, to find solutions due to the changes in the legislation, to the view on retirement age and to the demands to keep people longer in work life. That's the background to our age management project. (HR b)

The concurrent attributive positioning and self-positioning were manifested in older workers internalizing the same perception of their own talent as they believed their management to have. Hence, congruence between attributed and self-positioning was reached. The status attribution depicted by Cohen and Zhou (1991) was expressed in older age comprising a negative status characteristic. The strength of its value became apparent through the aim of retaining older workers in the organization being described as a function of pressing circumstances rather than in relation to older workers' talent. Retaining older workers was justified not by any qualitative characteristics but by older workers' quantity and availability in times of talent shortage.

The interview statements suggested that valuation of employees corresponded with the perceived ability to promote, embody and understand certain products. In this process, younger workers' talent appeared to be associated with new products and older workers' talent, to a greater extent, with older products that were about to be discontinued. Consequently, older workers were gradually phased out through an aged-based division, where older workers are put to work on the company's older products.

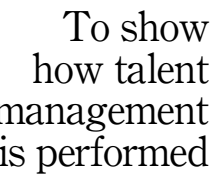

361 


\section{JOEPP 8,4}

I think the skill shift matches, they are a bit older who work with the old products. The department now with electrification was started in 2013. It's not an old department. It was then 3 groups. Now 3 years later it's 3 sections with 4 groups each. It has grown from 3 to 12 in 3 years. (Manager c)

Rather than being viewed as contributors, older workers were perceived as running the risk of contaminating the organization with their "outdated talent". Several statements revealed a perception of older workers as an obstacle rather than an asset. The quotes questioning the concept and practice of knowledge transfer could all be said to demonstrate a positioning of older workers' talent as denied and refused.

The interview statements compiled under this heading illustrated the principles of Cohen and Zhou (1991). When digital technology became a highlighted part of the talent concept, age was activated as a status characteristic that affected the valuation of employers. The notion of rising age comprising a negative status characteristic was articulated in the disconnection between the business case and talent associated with older workers. As older workers' talent remained disconnected from the business case, it became peripheral and invisible.

\section{The Pygmalion effect at work: attributed positioning and self-positioning in disagreement producing resigned and marginalized older workers}

In other cases, the self-positioning and the attributed positioning did not coincide. This was the case, for example, when older workers highlighted the value of their own talent and contribution to the organization, while managers actively opposed the transfer of knowledge from older to younger employees with reference to the short life cycles of talent pertaining to new technology. Talent related to digitalization and electrification was given preference in knowledge transfer processes quickly becoming obsolete. At the same time, older workers' talent within this field was viewed as quickly becoming obsolete and hence not important to transfer. The talent of older employees was hence rejected through the positioning acts within the very areas that the TM practices were focusing on. One result of the discrepancy between self-assessment and perceived attributed assessment or absence thereof was disappointment and resignation among the older employees. Several older employees described a declining commitment and interest in knowledge transfer in tandem with the perceived lack of interest from management in securing their talent within the organization.

Resisting the attributed devaluation apparent in managers' attitudes toward knowledge transfer, the older workers themselves valued their talent and what they brought to the organizational table. Several older workers expressed a positive self-image regarding their talent, revealing a gap between attribution and self-positioning for the older workers.

I have the experience, I know what to do, I know how to think and so on. I think I'm quite alone about that. Would something happen after I've retired, then I would be able to come back to work and go alongside the new, younger so to speak, that has taken over, to support and help. (Employee c)

Several statements revolved around possessing unique knowledge that stacked up well against other workers' talent.

I have collected knowledge and experience during all the years I have worked in the organization not related to a particular job. I have wider range of experience than the others. (Employee f)

Longstanding experience was frequently identified as the foundation for the talent the older workers perceived themselves as having. This also reflected aspect in their self-perceived type of talent - intangible qualities not easily grasped - that the workers argued made it difficult to readily transfer to successors.

My talent is built on many years in the organization and my way-of-thinking. It is very hard to transfer and is depending in finding another person that thinks in the same way. It is very much depending what you are interested in. (Employee b) 
Devaluation related to management's lack of initiating TM practices and processing of knowledge transfer was brought up in various ways in the interviews. Feelings of one's talent going unrecognized in some cases related to the way retirement processes were handled by management. Practical matters rather than the loss of talent brought about by someone's retirement being emphasized were mentioned as an example of this by one interviewee.

My manager emphasizes the importance of handing over my accesses and keys but no one takes care of my knowledge. There has been plenty of time to prepare for my retirement. (Manager e)

A depicted response to the experienced absence of initiative on behalf of management was resignation. The older workers, who described their experience-based talent as valuable, were left disheartened by managements' lack of active interest in maintaining their talent within the organization. Engagement regarding how to retain one's talent within the organization was described by some older workers as declining with the perceived lack of engagement from management.

I no longer prepare for how to pass on my knowledge. I have a lot of documents and manuals but what should I do with it? Should I just press the delete button or who should I hand it over to? It makes me sad that there is no one to hand it over to. (Manager b)

Interviewees articulated feelings of having one's talent unrecognized or misunderstood, i.e. what in Czarniawskas model would correspond to position denied in the attributive positioning by others. Instead of being attributed high status toward the end of their working life, the older workers frequently reported experiences of having their position denied or gone unnoticed. One such account conveyed the feelings of invisibility as follows:

Some days after my 65th birthday my manager came to me in panic and said "Oh, you are 65! When will you retire?”. It feels like fading away, I could have left without saying anything. (. . .) I do a lot more than I should. More is needed and I have the knowledge and the experience to do it. But all these extra things I am doing, who will keep on doing them when I have left this company? (. . .) I know that HR puts it on the manager. Everything is on the manager today, but the managers have so much to do. They cannot keep up with these issues. In the old days there was a HR person in each department, who helped and fixed and all that. (Employee a)

Frequently, the statements voiced a sentiment of disappointment in not having one's talent seen and acknowledged. Analyzed through Czarniawska's positioning acts, the interview statements demonstrated a combination of self-positioning and positioning contested/ resisted. The older workers expected to have their experience valued and made visible, but expressed that these expectations had not been met, illustrating the divergence between the older workers' self-assessment and the assessment that they perceived their management to make of them. The interview statements indicated a lack of organizational practices that enabled visibility, recognition and positioning of older workers' talent.

\section{Valued verbally but not in practice: older workers' talent acknowledged by older workers and the management but not by the talent management practices}

In yet another case, the difference between self-positioning and attributed positioning in relation to older people's talent was not so much about a difference in value. Instead, the discrepancy was found between the valuation of older workers' talent and the organization's TM practices. This was the case when the TM practices were not able to utilize older employees' contextual organizational knowledge and possession of effective global social networks. Such tacit knowledge related to the global organizational setting and social networks acquired over a long period of time were described as valuable by both older workers and managers. This valuation, however, was not put into practice as tacit forms of knowledge were deemed difficult to transfer from one person to another.

To show
how talent
management
is performed

363 

$\underset{8,4}{\text { JOEPP }}$

\section{4}

As a narrow "business case" approach on efficiency or what could be labeled as NPM strategies and practices stood in the way of transferring the type of knowledge that older workers were associated with, their tacit knowledge was valued in theory but not in practice. As experience-based knowledge was not included in the TM work, the talent of older workers was not recognized or made visible in the global TM practices in the organization.

Experience-based knowledge pertaining to global social networks was a type of talent that older workers were typically associated with.

Valuable competence for the organization is experience from a long work life, silent knowledge that is inside your finger-tips, for example the social network. Focus group interview with three older employees (2 from unit B and 1 from unit A)

While this type of talent was referred to as valuable and worthy of being transferred, several interviewees, particularly the older workers themselves, spoke of it as a form of knowledge that did not readily lend itself to being transferred.

Experience is not easy to transfer because it is in your head and impossible to tell to another person. Focus group interview with three older employees ( 2 from unit B and 1 from unit A)

Tacit knowledge, such as organization-specific and network-related knowledge, constituted the part of the older workers' talent that was considered worthy of being preserved within the organization. The employed NPM approach however was not compatible with the transfer of such knowledge, which led to a marginalization of older workers' talent and a focus on talent associated with younger workers. Several interviewees stressed that knowledge transfer presupposed a setup in which seniors and juniors worked side by side. Such an "overlap" practice in which older workers were used in the transitional phase in order to get the "new talent" in place was requested by employees but regarded as costly by management. Some managers stressed that they would have liked to hire someone new before an employee retired, but said that headcount posed a problem. Estimating that a year's overlap would be desirable, they stated that they were "lucky" if they got three months' overlap. In their desire for an extended overlap period, managers expressed that the older workers' talent was valued. However, the lack of overlap granted meant that the TM practices did not reflect this valuation. It was expressed verbally but not in practice.

Various interviewees described what they perceived to be a lacking understanding on the part of the TM of how to successfully transfer knowledge from senior to more junior workers.

The company tries to streamline by not allowing two people to walk alongside each other. They seem to think that this will lead to a higher degree of efficiency. The company will never appoint a person to sit and learn, because they'll never let a competent employee support another person instead of going into high gear and solve problems. This is wrong. The company has to start working in a different way. (Manager a)

The view of what constituted talent was manifested in the attitude and TM practices related to knowledge transfer as well as in the focus on recruiting young employees with digital technology skills. It was also manifested in which employees were associated with the company's new products, and who got to represent the products and ultimately the company internally as well as externally. Since the older workers' talent was not connected to the business case, knowledge retention was not defined as a central TM practice. This, in turn, contributed to the talent of older workers not only being actively denied but also failing to be positioned as talent by going unnoticed. Older workers were indirectly eliminated from the perceived talent pool by never making it to evaluation processes, in which talents were constructed as such within the organization. 


\section{Discussion}

Illustrating how the meaning of talent and age emerge in performative processes, the present study confirms talent and age as continuously evolving and fluid categories. The aim of the current article was to gain insight into how positioning acts, related to an organization's recognition of older employees' talent, interact to produce certain outcomes. To this end, we studied the dynamic between Czarniawska's attributive and self-positioning in negotiating selves, value and status. An overarching emerging pattern revealed that older workers' talent failed to be positioned within the studied organization. This failure was linked to (1) older workers' talent being disconnected from the business case and thereby made peripheral and (2) the absence of organizational practices that could render the talent associated with older workers visible. The previous literature has emphasized how workers over the course of their careers acquire valuable career capital consisting of tacit knowledge and both global and local social networks. In our study, the interviews with older workers regarding their selfperception related to experience-based knowledge mirror this literature insofar as they confirm the existence of an experience-based career capital. While our study hence confirms the acquirement of career capital over time, it also shows that the stated career capital is not valued in TM practices and links this failure to a combination of perceptions of age within the organization and NPM strategies employed by the organization. NPM strategies on TM that reward measurability and easily transferable talent components contribute to rendering the talent associated with older workers, i.e. global and local social networks and contextual tacit knowledge, invisible. While this type of global talent is valued and recognized in the organization, the TM practices are not designed to secure it, whereby the talent avoids positioning and runs the risk of becoming extinct. When new technology is incorporated as a central component in organizations' global talent concepts, age increasingly becomes linked to status. Since both technology and propensity for change are strongly associated with youth, the dualistic perception of age in organizations make for constructions of older workers as technology adverse and stagnated. The very use of the global talent concept can contribute to marginalizing older workers and rendering them invisible and unrecognized in the organization. The concept of talent evokes associations of being young, promising and at the beginning of one's career. It also entails a malleability aspect consistent with the appeal in contemporary organizations for flexibility and mobility. Talent in this respect comes to signify raw talent that can be refined based on the organization's preferences and needs. The association between talent and young age is visible in the lack of age-inclusive training and underrepresentation of older employees in TM programs (Armstrong-Stassen and Templer, 2005) as well as in the allocation of high talent ratings within organizations, where young and male employees tend to be overrepresented (e.g. Festing et al., 2015; Swailes and Blackburn, 2016).

In contrast to Ng and Feldman (2014) and Dickmann et al. (2018), who emphasize the value of career capital and social networks, our study thus demonstrates that while such forms of capital are said to be valued within the organization, there is little in the way of TM practices suggesting that they actually are. Based on our findings, we conclude that TM and GTM practices do not support or prioritize retention of the type of talent attributed to older workers, whereas types of talent associated with younger workers, e.g. drive and mobility, are favored by these practices. Combining positioning acts and status mechanisms has allowed us to gain detailed knowledge of how inclusion and exclusion occur in an organizational setting. Like previous studies, we recognize the value of career capital achieved over time. We contribute to this literature by adding that value, for its realization, presupposes recognition within the context where it is supposed to work as currency. In our study, this point was illustrated by older workers' talent being recognized verbally but not through the TM practices employed by the organization.

Our study carries several implications for practice and future research. Causes of the failure to capitalize on older workers' talents can be traced, at least in part, to the perception of

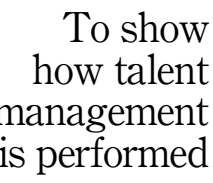

365 

$\underset{8,4}{\text { JOEPP }}$ talent, mobility and age. In accordance with the notion of Jeanes et al. (2015) of mobility as developed in a dynamic interaction between people and their contexts, our findings illustrate how others' perception of one's mobility shapes one's actual mobility, thereby creating selffulfilling prophecies. Being perceived as having a global social network and as mobile by one's surroundings means being granted opportunities for mobility that further reinforce and confirm the initial perception of one as mobile. The transformation brought about by digital technology calls for a wider mobility concept that extends further than to physical movement across geographical areas. Mobility, in the digital era, comes to signify a fluidity across social and cultural spheres, an openness to boundarylessness between social worlds that break up distinctions of private and professional, leisure and business, etc. Moving away from a dichotomous perception of age would likely promote a more inclusive TM practice by dismantling the link between age and status. Our findings hence call for a wider and more dynamic perception of both mobility and age in order to allow for inclusion of more types of competence as well as more types of workers. Endorsing the proposal of Festing et al. (2015) of a conceptualization for a more inclusive TM, our findings raise concerns of negative effects of TM practices on workforce diversity. Furthermore, our findings support the call of Dickmann et al. (2018) for a broader view of TM that rests on a dynamic perception of career capital procurement, through which career capital is seen as acquired over time and entailing a broad range of components, and where this view is also clearly translated into the TM practices of organizations. Our study highlights potential effects of TM related to future workforce diversity. In light of our findings and in agreement with the call of Sheehan and Anderson (2015), we stress the importance of research on TM outcomes in relation to workplace diversity.

A limitation of our study is that it was carried out in a single multinational organization. For future studies, it would be interesting to include a greater number of organizations and to also include observations in the data. Broadening the scope pertaining to age and gender, we also believe could contribute further to a nuanced understanding of the positioning and inclusion/exclusion processes depicted in the present article. This study has focused on the positioning acts of management and HR and their consequences for TM related to age. Using the same framework, it would be interesting to dedicate further research to more detailed studies of various actors' perspectives, including older and younger employees. Such research could entail analysis of each of type of actor as well as analysis of the negotiation between actors' performative positionings and its implications for TM and age.

\section{Conclusion}

The conclusions of this study are threefold. First, social capital based on long experience and global and local social networks are not central in the positioning acts and the production of status in the performance of TM in the studied global company. Second, mobility identity constructions are highly influenced by perceptions and social discourses on age, juniority and seniority. Third, managers and HRM specialists are not in an active way linking the definition of talent within the company to the performance of TM. Instead, the digital transformation of professional practices within global multinational companies is a most influential actant in the definition on what and whom is regarded as talent, rising star or not positioned at all. The NPM strategies employed by many organizations - focused on efficiency through cost cuts and slimming - also regulate the definition of talent by allowing for some types of talent and not others to be transferred between organizational members.

Our study, in line with Collings et al. (2019), highlights the need for further research on the relationship between how TM is performed in practice and the performance of multinational companies. In order to develop a more detailed understanding of this relationship, we suggest a frame of reference based on a performative perspective. This would take aim at how TM is 
performed through positioning acts and status constructions. Furthermore, it would consider the effects of TM on recognition and visibility of talent and human capital, especially in regards to perceptions regarding age, seniority and juniority.

\section{References}

Ahmed, A.M., Andersson, L. and Hammarstedt, M. (2012), "Does age matter for employability? A field experiment on ageism in the Swedish labour market", Applied Economics Letters, Vol. 19 No. 4, pp. 403-406.

Armstrong-Stassen, M. and Templer, A. (2005), "Adapting training for older employees: the Canadian response to an aging workforce”, Journal of Management Development, Vol. 24 No. 1, pp. 57-67.

Chiu, W.C.K., Chan, A.W., Snape, E. and Redman, T. (2001), "Age stereotypes and discriminatory attitudes towards older employees: an east-west comparison”, Human Relations, Vol. 54 No. 5 , pp. 629-661.

Cohen, B.P. and Zhou, X. (1991), "Status processes in enduring work groups", American Sociological Review, Vol. 56 No. 2, pp. 179-188.

Coile, C. (2015), "Economic determinants of employees' retirement decisions", Journal of Economic Surveys, Vol. 29 No. 4, pp. 830-853.

Collings, D.G. and Mellahi, K. (2009), "Strategic talent management: a review and research agenda", Human Resource Management Review, Vol. 19 No. 4, pp. 304-313.

Collings, D.G., Mellahi, K. and Cascio, W.F. (2019), "Global talent management and performance in multinational enterprises: a multilevel perspective", Journal of Management, Vol. 45 No. 2, pp. 540-566.

Corbin, J. and Strauss, A. (2008), "Grounded theory research: procedures, canons, and evaluation criteria”, Qualitative Sociology, Vol. 13 No. 1, pp. 3-21.

Czarniawska, B. (2013), "Negotiating selves: gender at work", Tamara Journal for Critical Organization Inquiry, Vol. 11, pp. 59-72.

Czarniawska, B. (2014), Social Science Research: From Field to Desk, SAGE Publications, London.

Denzin, N.K. and Lincoln, Y.S. (2011), The SAGE Handbook of Qualitative Research, 2nd ed., SAGE, London.

Dickmann, M., Suutari, V., Brewster, C., Mäkelä, L., Tanskanen, J. and Tornikoski, C. (2018), "The career competencies of self-initiated and assigned expatriates: assessing the development of career capital over time", The International Journal of Human Resource Management, Vol. 29 No. 16, pp. 2353-2371.

Dries, N. (2013), "Talent management, from phenomenon to theory", Human Resource Management Review, Vol. 23 No. 4, pp. 267-271.

Faist, T. (2013), "The mobility turn: a new paradigm for the social sciences?", Ethnic and Racial Studies, Vol. 36 No. 11, pp. 1637-1646.

Festing, M., Kornau, A. and Schäfer, L. (2015), "Think talent-think male? A comparative case study analysis of gender inclusion in talent management practices in the German media industry", The International Journal of Human Resource Management, Vol. 26, pp. 707-732.

Flynn, M. (2010), "Who would delay retirement? Typologies of older employees", Personnel Review, Vol. 39 No. 3, pp. 308-324.

Furunes, T. and Mykletun, R.J. (2007), "Why diversity management fails: metaphor analyses unveil manager attitudes", International Journal of Hospitality Management, Vol. 26 No. 4, pp. 974-990.

Gallardo-Gallardo, E., Dries, N. and González-Cruz, T.F. (2013), "What is the meaning of 'talent' in the world of work?”, Human Resource Management Review, Vol. 23 No. 4, pp. 290-300.

Gallardo-Gallardo, E., Nijs, S., Dries, N. and Gallo, P. (2015), "Towards an understanding of talent management as a phenomenon-driven field using bibliometric and content analysis", Human Resource Management Review, Vol. 25 No. 3, pp. 264-279.

\section{To show \\ how talent management is performed}




\section{JOEPP 8,4}

Golden-Biddle, K. (1993), "Appealing work: an investigation of how ethnographic texts convince", Organization Science, Vol. 4 No. 4, pp. 595-616.

Holland, D. and Scullion, H. (2019), "Towards a talent retention model: mapping the building blocks of the psychological contract to the three stages of the acquisition process", The International Journal of Human Resource Management, Vol. 32 No. 13, pp. 2683-2728.

Ilmarinen, J. (2012), Promoting Active Ageing in the Workplace, European agency for safety and health at work, available at: https://osha.europa.eu/en/tools-and-publications/publications/articles/ promoting-active-ageing-in-the-workplace/view.

Jeanes, E., Loacker, B., Śliwa, M. and Weiskopf, R. (2015), "Mobilities in contemporary worlds of work and organizing", Theory and Politics in Organizations, Vol. 15 No. 4, pp. 705-723.

Kaghan, W. and Lounsbury, M. (2011), "Institutions and work", Journal of Management Inquiry, Vol. 20 No. 1, pp. 73-81.

Kerr, S.P., Kerr, W., Özden, C. and Parsons, C. (2016), "Global talent flows", Journal of Economic Perspectives, Vol. 30 No. 4, pp. 83-106.

Lahey, J. (2008), "Age, women, and hiring. An experimental study", The Journal of Human Resources, Vol. 43 No. 1, pp. 30-56.

Latukha, M. (2015), "Talent management in Russian companies: domestic challenges and international experience", The International Journal of Human Resource Management, Vol. 26 No. 8, pp. 1051-1075.

Loretto, W. and White, P. (2006), "Employers' attitudes. Routines and policies towards older employees”, Human Resource Management Journal, Vol. 16 No. 3, pp. 313-330.

McDonnell, A., Collings, D.G., Mellahi, K. and Schuler, R. (2017), "Talent management: a systematic review and future prospects", European Journal of International Management, Vol. 11 No. 1, pp. 86-128.

Meyers, M.C. and Van Woerkom, M. (2014), "The influence of underlying philosophies on talent management: theory, implications for practice, and research agenda", Journal of World Business, Vol. 49 No. 2, pp. 192-203.

Morgan, D.L. (1997), Focus Groups as Qualitative Research, SAGE, Thousand Oaks, CA.

Munnell, A., Sanzenbacher, G. and Rutledge, M. (2018), "What causes employees to retire before they plan?”, Journal of Retirement, Vol. 6 No. 2, pp. 35-51.

Neumark, D., Burn, I. and Button, P. (2019), "Is it harder for older employees to find jobs? New and improved evidence from a field experiment”, Journal of Political Economy, Vol. 127 No. 2, pp. 922-970.

Ng, T.W. and Feldman, D.C. (2014), "Subjective career success: a meta-analytic review", Journal of Vocational Behavior, Vol. 85 No. 2, pp. 169-179.

Nonaka, I. and Takeuchi, H. (1995), The Knowledge-Creating Company: How Japanese Companies Create the Dynamics of Innovation, Oxford University Press, Oxford.

Remery, C., Henkens, K., Schippers, J. and Ekamper, P. (2003), "Managing an aging workforce and a tight labor market: views held by Dutch employers", Population Research and Policy Review, Vol. 22 No. 1, pp. 21-40.

Riach, K. and Kelly, S. (2015), "The need for fresh blood: understanding organizational age inequality through a vampiric lens", Organization, Vol. 22 No. 3, pp. 287-305.

Riach, P.A. and Rich, J. (2006), An Experimental Investigation of Age Discrimination in the French Labour Market, IZA Discussion Paper no. 2522, Institute Study Labor, Bonn.

Riach, P.A. and Rich, J. (2010), "An experimental investigation of age discrimination in the English labor market", Annals of Economics and Statistics, Vols 99/100, pp. 169-185.

Rubery, J., Keizer, A. and Grimshaw, D. (2016), "Flexibility bites back: the multiple and hidden costs of flexible employment policies”, Human Resource Management Journal, Vol. 26 No. 3, pp. 235-251. 
Sheehan, M. and Anderson, V. (2015), "Talent management and organizational diversity: a call for research - editorial", Human Resource Development Quarterly, Vol. 26 No. 4, pp. 349-358.

Sheller, M. and Urry, J. (2006), “The new mobilities paradigm”, Environment and Planning A: Economy and Space, Vol. 38 No. 2, pp. 207-226.

Sheller, M. (2014), "The new mobilities paradigm for a live sociology”, Current Sociology, Vol. 62 No. 6, pp. 789-811.

Silverman, D. (2013), Doing Qualitative Research: A Practical Handbook, SAGE Publications, Los Angeles, London, New Delhi, Singapore, Washington, DC.

Swailes, S. and Blackburn, M. (2016), "Employee reactions to talent pool membership", Employee Relations, Vol. 38, pp. 112-128.

Vaara, E., Sarala, R.M., Stahl, G.K. and Björkman, I. (2012), "The impact of organizational and national cultural differences on social conflict and knowledge transfer in international acquisitions", Journal of Management Studies, Vol. 49 No. 1, pp. 1-27.

Vaiman, V., Scullion, H. and Collings, D. (2012), “Talent management decision making”, Management Decision, Vol. 50 No. 5, pp. 925-941.

Van Dalen, H.P., Henkens, K. and Schippers, J. (2010), "Productivity of older employees: perceptions of employers and employees", Population and Development Review, Vol. 36 No. 2, pp. 309-330.

Van Dongen, M.A.D. and Loos, J.C. (2018), "Think tank-addressing the business challenges of an aging workforce", Global Business and Organizational Excellence, Vol. 37 No. 4, pp. 58-65.

\section{Further reading}

Flyvbjerg, B. (2006), "Five misunderstandings about case-study research", Qualitative Inquiry, Vol. 12 No. 2, pp. 219-245.

Gallardo-Gallardo, E. and Thunnissen, M. (2016), "Standing on the shoulders of giants? A critical review of empirical talent management research", Employee Relations, Vol. 38 No. 1, pp. 31-56.

Kirk, S. (2016), "Career capital in global kaleidoscope careers: the role of HRM", The International Journal of Human Resource Management, Vol. 27 No. 6, pp. 681-697.

Yin, R.K. (2009), Case Study Research: Design and Methods, SAGE, Thousand Oaks, CA, Vol. 5.

\section{Corresponding author}

Nanna Gillberg can be contacted at: nanna.gillberg@gu.se

For instructions on how to order reprints of this article, please visit our website:

www.emeraldgrouppublishing.com/licensing/reprints.htm

Or contact us for further details: permissions@emeraldinsight.com 